mitter, feeding experiments and their results, the working out of the history of the parasite in the fly (the whole life-cycle of the parasite is fully considered in a paper by Major Shortt), and refers to the parallel work of Patton and Hindle in China. The final link in the chain of proof, namely, transmission from man to a human volunteer by means of the sandfly, is still lacking, probably owing to the fact that man, instead of being very susceptible, is extremely resistant to infection by kala-azar.

There are numerous papers on helminthology and on medical entomology; but these notes must close with a mention of Mr. Senior-White's paper on progress towards the realisation of the biological control of mosquito breeding, in which, after recounting the older methods, the author considers the connexion between the hydrogen-ion concentration of the water and the species of mosquitoes that breed in it. Acidity other than that due to carbon dioxide is definitely inhibitory to anophelines; but only extremes of 'natural' $p \mathrm{H}$ have any such effect. The presence of very small amounts of ammonia, however, are destructive to larvæ; and the probability that bacteriophages (v. sup.) can be isolated by which the nitrifying bacteria can be destroyed, and hence the conversion of ammonia into nitrites and nitrates delayed, gives a hope that practical measures may be devised on these lines.

Perhaps it is scarcely necessary to add that all the activities of the Congress were not on these strenuous lines. The programme specifies such things as an evening reception by H.E. the Governor of Bengal at Government House, another by the Trustees of the Indian Museum at the Museum, a conversazione by the Asiatic Society of Bengal, a garden party at Government House, river trips and 'bus tours, visits to works, scientific cinema films, a play in an Indian theatre, as well as other diversions. The scientific meetings concluded on Dec. 11, after which three tours were arranged, one through northern India, one through southern India (these lasting a fortnight), and one through Bihar and Orissa (lasting a week). The "Souvenir-The Indian Empire," presented to all members, is "a brief description of the chief features of India and its medical and sanitary problems"; it fulfils a similar function to the Local Handbook of the meetings of the British Association. Among its 18 chapters are included a résumé of Indian history, and accounts of the history of European medicine in India, of indigenous systems of medicine, of Indian archæology, zoology, botany, geology, weather, and art. Its 340 pages are illustrated by 20 plates of photographic reproductions, several --including the frontispiece, a magnificent peak in the Sikkim Himalayas of great beauty. Everything seems to have been done to make the Congress a success ; and the members can scarcely fail to have enjoyed an intensely interesting as well as a very profitable visit to Calcutta.

\section{J. Stephenson.}

\title{
The Origin of the Japanese Earthquake of I923.
}

D. N. YAMASAKI, professor of geography in the Imperial University, Tokyo, contributed to the official report some valuable physiographic studies on the Japanese earthquake of 1923, which

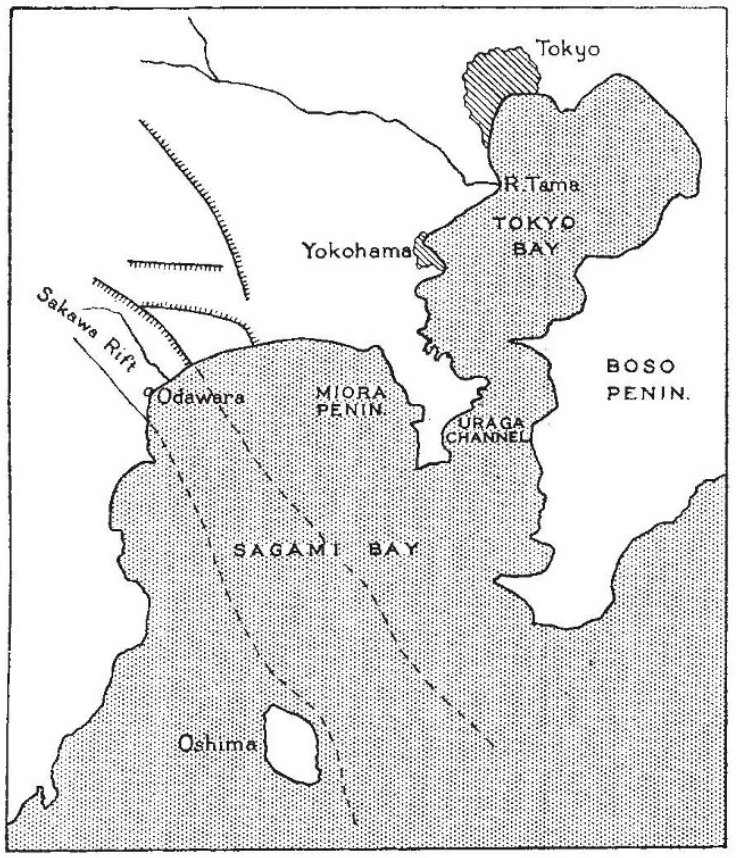

FIG. 1.

he has recently brought to the knowledge of western readers by translating them into English (Jour. Fac. Sci., Imp. Univ., Tokyo, vol. 2, pp. 77-119; 1926). They are of great interest, chiefly on account of the light which they throw on the origin of this remarkable earthquake.

No. 3044, Vor. 121]
The principal features of Prof. Yamasaki's map are here reproduced (Fig. 1). The river Sakawa runs into the Bay of Sagami on its north-west side. The valley is part of a remarkable rift valley, bounded on the north-east side by a fault-scarp from 200 to 300 metres in height. It was formed by blocking movements of comparatively recent date. Earthquakes, indeed, still occur in the district, one of the latest being the strong Odawara earthquake of 1633 . The earthquake of 1923 was very severe in this part. Many villages at the foot of the scarp were totally ruined and the level surface of the fields was thrown into gentle undulations. Still more remarkable than the rift valley on land is its continuation into Sagami Bay. A great trench runs along the axis of the bay in the direction $\mathrm{S} .35^{\circ} \mathrm{E}$. Near the bottom of the trench the slope is gentle, while the straight side walls are steep and high. The north-east wall is an extension of the fault-scarp on the same side of the Sakawa valley, while the south-west wall is also a steep scarp passing a short distance to the east of the volcanic island of Oshima.

Before the earthquake of 1923, the depth of the trench varied from 1500 to 2000 metres. On the north-east side of the trench, the submarine plateau consists of two steps, the lower one $12 \mathrm{~km}$. wide at a depth of from 1000 to 700 metres, the upper one forming a shelf with a depth of less than 200 metres. One other feature deserves notice-a fiord-like furrow along the floor of the Uraga Channel, with a branch on the east continued into the Boso peninsula as the depressed tract around Tateyama.

The earthquake of 1923, in Prof. Yamasaki's opinion, may be considered as the direct effect of an enormous blocking movement in the district. The most remarkable displacement was of course that which occurred in Sagami Bay. The subsidence was greatest, from 100 to 210 metres, along the axis of the trench. The margin of the uplifted block on its north-east side was raised 250 metres, that on the south-west side 120 metres. Besides these tilted blocks in the deep sea, the shelf of land along the 
coast was also uplifted, though to a much less extent. The land was tilted as a whole with its raised margin to the south, the uplift gradually decreasing to the north as far as the Tama valley, after which elevation gave place to depression, never great in amount but covering a wide area. In consequence of these great movements, many fault-lines have newly appeared in the Boso and Miura peninsulas. Slips also occurred on the sea-bed where the slope is steep, those on both sides of the Uraga furrow being the most remarkable.

In this and other memoirs, attention is concentrated chiefly on the vertical displacements. The re-survey of the district has, however, revealed horizontal move- ments. These are described by Prof. A. Imamura in a brief paper read before the International Union of Geodesy and Geophysics at the Prague meeting in September last. Assuming that the positions of two points about fifty miles north of Tokyo have remained unmoved, it appears that the island of Oshima has shifted 3.78 metres in the direction N. $8^{\circ}$ E., Manzirodake on the west coast of Sagami Bay $2 \cdot 86$ metres N. $9^{\circ}$ E., Sengen-yama on the north coast 2.75 metres N. $112^{\circ}$ E., and Nokogiri-yama on the east coast 2.57 metres $\mathrm{N} .145^{\circ} \mathrm{E}$. Thus, generally speaking, the whole epicentral district has made a clockwise twist about a vertical axis somewhere in Sagami Bay.
C. D.

\section{British Industries Fair.}

THE distinguished general who called the English a "Nation of Shopkeepers" was aiming a scathing insult at our people. By the same token, Adam Smith and the older economists must have turned in their graves when the Government decided to take active steps for the encouragement of commerce. Times have changed. We now aspire to the proud title of a "Nation of Shopkeepers." In order to pay the appalling bill for the War and to restore our country to its pristine wealth, production and trade, especially export trade, must be stimulated by every resource, private or public. Faced by intensified foreign competition and the loss of our pre-eminence in the control of raw material, we are turning to scientific research, to a higher organisation of industry, and not least to a reasonable propaganda on the commercial side. A useful exhibition of our industrial effort is now organised annually by a Government department, the Department of Overseas Trade (Development and Intelligence).

This year's Fair, held in London and Birmingham on Feb. 20-Mar. 2, showed a marked increase in the number of exhibitors and the range of industry represented. By the admission of the general public during the daytime at a nominal charge, the cathedral-like silence of the earlier fairs has been replaced by a livelier atmosphere, without derogation of the serious purpose the organisers of the Fair have in view. Noticeable this year was the evidence of rapid exploitation of recent scientific discoveries. The British Drug Houses, Ltd., for example, already have on the market Vitamin $\mathrm{D}$ in the form of a sugared pill, equivalent to so many hours of sunshine. This firm has also prepared a form of malt containing three vitamins. Several forms of apparatus, some of them fitted with electric clocks, were on view for the administration of ultra-violet rays. Even powder puffs are now treated with these rays.

In the wireless section, many portable sets were shown, giving excellent results, in some instances at quite a moderate price. Lilley's sounding instrument warns a ship approaching rocks and records the depth of water under a ship's bottom. Even in the realm of toys, science has raised its standard. 'Thirsty' is the name of a toy dog the protruding tongue of which indicates changes of weather. The whole world will welcome the new instrument for testing the accuracy of singers' voices, exhibited by the Institute of Patentees.

Complexity is not necessarily a characteristic of modern invention. There is, for example, a simple pad called the 'Solapad,' worn next to the skin over the abdominal nerves, which claims to prevent travel sickness in its various forms-sea, train, motorcar, etc. The Ice Store Portable Refrigerator makes ice of the purest quality at an operating cost of one penny per day. Attention may again be directed to the 'Thermega' electro-radiant blanket, a simple and cheap but most useful electrical application. We have no difficulty in accepting the makers' assurance that dampness in beds is a source of great danger, lowering the vitality even when not a direct cause of disease. The blanket has also many obvious medical applications. Messrs. Grieve and Gordon are extending the use of eucalyptus oil as a disinfectant. Imperial Chemical Industries, Ltd., again provided an interesting exhibit, enlivened by a cinema show. Their nitrogen campaign for the improvement of grassland is making good progress. A new fertiliser, called 'Nitrochalk,' has been placed on the market, consisting of a mixture of ammonium nitrate and dried carbonate of lime. Ammonium nitrate is unsuitable as a direct fertiliser, but can be made available as a fertiliser by mixing with carbonate of lime, of which the company has an ample supply at Billingham. The mixture has a nitrogen content of 10 per cent., and its price will be such that the farmer will only be paying for the nitrogen, the lime-itself a valuable fertiliser in certain soil conditions-being given to him free of charge.

Apart from the evidence provided by statisties of sales effected by the exhibitors, the visitor will be left in no doubt as to the usefulness of this Fair, and for those who are despondent about the future of British industry, it should serve as a tonic.

\section{Spectra and Atoms.}

"SPECTRA and Atoms" formed the subject of a lecture by Prof. A. Fowler before the Chemical Society on Feb. 23, when he gave in brief outline an account of the relations existing between series lines in the spectra of elements, and discussed how these relations harmonise with modern views concerning the electronic configuration of the atom.

Early investigations were primarily directed to the identification of regular series of lines which can be represented by simple formulæ, each line being described as the difference of two wave-numbers or terms. Recognition was early extended to different types of series-principal, diffuse, sharp, and fundamental-and Rydberg showed how the various series in the same spectrum are closely interrelated, leading to a simplification in the mode of representation. Prof. Fowler proceeded to discuss the application of Ritz's combination principle, and the restrictive effect therein of certain selection rules. In some spectra, all terms other than those of $S$ type have two values, giving rise to series consisting of doublet lines, and in others three values yielding triplets, but a combination of two doublet terms does not give four lines, and one of two triplet terms yields

No. 3044, VoL. 121$]$ 